\title{
JAWARA DALAM PERUBAHAN SOSIAL DI MASYARAKAT BANTEN
}

\author{
Oleh: Ato'ullah*
}

\begin{abstract}
Jawara is part of the social structure in society since time immemorial Banten which consists of, ulama, umaro, and jawara. Because of its advantages supernatural, they actually have a noble obligation which protect the society and defend the interests of religion. However, after the transfer of power from the sultanate to the colonial government, the social structure of ulama-umaro-jawara change become, jawara-umaroulama. Their position in society became stronger and shifted their political behavior for the purposes of economic interests. In this context, they are trying to maintain the legitimacy of the leadership provided by the local culture. They tried to control the strategic institutions in economics and local politics while stabilizing external network to establish a good relationship with other elite, such as bureaucrats, party and military. This relationship is symbiotic, which stresses the advantages for each party. With a system of government that adopts oligarchy and conditions such Banten, the development of democracy and civil society in Banten became a very serious issue.
\end{abstract}

Keyword: Jawara, power and social change.

\section{LATAR BELAKANG}

Pada tanggal 4 Oktober 2000 merupakan momentum yang sangat bersejarah bagi masyarakat Banten pada khususnya karena pada tanggal itu Banten secara resmi menjadi Propinsi yang ke-30 di Republik ini, terlepas dari Propinsi Jawa Barat sebagai propinsi Induk yang dulunya masih jadi karesidenan Banten. Pada hakikatnya perjuangan masyarakat banten ingin lepas dari Jawa Barat dimulai dari tahun 1962. Microb (1998) mengatakan bahwa perjuangan masyarakat Banten pada waktu itu mempunyai beberapa kendala yang salah satunya adalah permasalahan politik Indonesia yang tidak memungkinkan Banten lepas dari Jawa Barat.

Kini setelah wilayah Banten menjadi propinsi tersendiri banyak mengalami perubahan yang signifikan. Perubahan sosial terutama dalam pembangunan propinsi Banten. Untuk kepentingan pembangunan propinsi terutama peningkatan ekonomi melalui PAD, masyarakat Banten yang terkenal dengan nilai relegiusitasnya, dan mempunyai sifat kejawaraan atau kebantenan di dalam menjalankan pemerintahan dengan menyerap banyak aspek dari budaya lokal. Pada kenyataannya pembangunan propinsi Banten saat ini tidak terlepas dari lapisan

\footnotetext{
* Dosen pada Program Studi Ilmu Administrasi Negara, Fakultas Ilmu Sosial dan Politik Universitas Sultan Ageng 
sosial utama yang ada, yakni Ulama (kyai) serta Jawara.

Untuk mengukuhkan kedudukannya, para Jawara dalam prakteknya membangun hubungan antar mereka serta membangun jaringan yang khas. Salah satu yang khas dari kehidupan antar mereka adalah rasa solidaritas yang tinggi. Apalagi jika yang menghadapi masalah tersebut adalah orang yang memiliki hubungan emosional, seperti adanya hubungan kekerabatan, "Se Guru-Se Elmu", pertemanan dan sebagainya.

Jaringan yang dibentuk oleh para Jawara tersebut kini tidak hanya bersifat non-formal atau tradisional tetapi juga memiliki organisasi masa yang tersendiri, yakni dengan terbentuknya P3SBBI (Persatuan Pendekar Pesilatan dan Seni Budaya Banten Indonesia). Organisasi para pendekar ini menghimpun lebih dari 100 perguruan yang tersebar di 17 propinsi di Indonesia. Organisasi ini berpusat di Serang, Ibu Kota Propinsi Banten, yang mana dulu dipimpin oleh almarhum $\mathrm{H}$. Tb. Chasan Sochib.

Otoritas tradisionalnya itu menjadi semakin kuat karena mereka mampu menguasai lembaga-lembaga strategis di bidang ekonomi dan politik, seperti Lembaga Pengembangan Jasa Konstruksi Daerah, Kadin Daerah dan lain sebagainya (ekonomi) dan wakil gubernur, walikota, lurah (politik), serta beberapa organisasi penting lainnya. Dengan penguasaan tersebut perilaku politik Jawara akhirnya mendapat legitimasi struktural.

Sementara itu, mereka pun kuat secara internal karena mendapatkan dukungan dari anak buahnya yang mudah dimobilisasi. Pola hubungan mereka yang bersifat patrimonial menjadikan anak buah terikat dengan pemimpin Jawara.

Jawara pun berusaha menjalin hubungan baik dengan E! it-elit lain, seperti birokrat, partai dan militer. Hubungan ini bersifat simbiosis yang sangat menekankan keuntungan bagi masing-masing pihak. Mereka menyebut Elit-elit tersebut sebagai "Mitra".

Dengan budaya politik, otoritas tradisional, penguasaan pada lembagalembaga strategis, legitimasi struktural, patrimonialisme pemimpin, dan hubungan simbiosis dengan elit lain, kekuasaan Jawara menjadi begitu kuat untuk konteks politik lokal. Dengan kekuasaannya itu, mereka berusaha mengontrol lembagalembaga yang dikuasainya, termasuk pula lembaga-lembaga swadaya masyarakat yang berseberangan dengannya dan terhadap kelompok-kelompok kritis lainnya.

Kekuasaan yang dipegang oleh segelintir Jawara dengan jaminan kekuatan fisik (magis dan persilatan) dan kemampuan ekonomi, mereka sebenamya merupakan bentuk sistem kekuasaan 
oligarki. Sistem ini semakin tumbuh subur karena selain mendapat dukungan dari mitra-mitranya juga karena pola interaksi yang mereka kembangkan adalah model patrimonial dimana ketua Jawara diakui sebagai patronnya. Dengan model ini, upaya kontrol (pengawasan) terhadap lembaga-lembaga yang berseberangan dan kelompok-kelompok kritis menjadi sangat efektif karena para Jawara, dengan model bentuk partisipasi kaula-partisipan, mudah untuk memobilisasi massa yang mereka miliki.

Dengan sistem pemerintahan yang menganut sistem oligarki dan kondisi Banten yang demikian, maka perkembangan demokrasi dan civil society di Banten menjadi persoalan yang sangat serius. Pada tingkat tertentu, proses yang berlangsung malah terjadinya decivilisasi yang membuat masyarakat Banten menjadi tidak berdaya, tidak mandiri, tak tercerahkan, dan dikuasai oleh ketakutan dalam menyuarakan hak individunya.

\section{Perumusan Masalah}

Dari uraian di atas ada permasalahan yang akan diangkat yakni, adalah bagaimana peranan Jawara dalam kehidupan sosial politik di Banten? Serta apa persepsi masyarakat Banten terhadap Jawara?

\subsection{Tujuan}

Tujuan dari kajian ini adalah pertama, mengetahui tentang peranan Jawara dalam politik di Propinsi Banten, serta keterlibatannnya di dalam pemerintahan. Kedua sejauhmana perubahan yang dibawa akibat intervensi Jawara dalam berbagai hal di tataran pemerintahan di Propinsi Banten.

\section{KERANGKA TEORITIS}

\subsection{Sumber-Sumber Struktural}

Dalam perubahan sosial yang ada di Propinsi Banten yang sangat kentara (dominan) peranannya adalah Jawara, sehingga yang sampai masuk dalam ranah pemerintahan di tingkat propinsi. Hal ini menjadi unik untuk dikaji. Selain itu penulis juga akan membahas permasalahan Banten dalam konteks perubahan sosial ini dengan menggunakan pisau analisa structural fungsional dan teori konflik sosial.

Sumber-sumber struktural memandang bahwa determinan dari perubahan sosial ditentukan oleh strukturstruktur yang ada dalam suatu masyarakat. Struktur tersebut bisa berupa pemerintah, sekelompok orang yang mempunyai masalah sehubungan dengan status, sekelompok elit, pemuda dan lain sebagainya. Sebagai contoh, pemerintah (baik pusat maupun daerah) dalam suatu masyarakat dapat dianggap sebagai 
28 JURNAL ILMIAH MIMBAR DEMOKRASI

pendorong atau perintang perubahan (Lauer 2003: 414).

Menurut kelompok Marxian, posisi negara adalah organisasi reaksioner yang melayani kepentingan kelas orang kaya, dan karena itu menentang perubahan. Sehingga kehadiran pemerintah menimbulkan keraguan apakah hadirnya pemerintah akan mampu membantu kelompok-kelompok yang termarjinalkan secara efektif ataukah tidak sama sekali.

Dalam konteks ini, kewajiban bagi kaum yang termarjinalkan untuk bergerak lewat revolusi guna mengambil alih tampuk kekuasaan dari kelompok kaum modal. Strategi revolusi kemudian mengambil 2 tahap yakni, revolusi borjuis (transisi feodal ke kapitalisme) dan revolusi proletariat (tranformasi dari kapitalisme ke komunisme) melalui partai pekerja (komunis).

Seperti telah disebutkan, sekelompok elit mempunyai peran penting dalam perubahan sosial. Meski kategori elit sangat beragam, akan tetapi terdapat kecenderungan umum dari kelompok ini yakni jumlahnya yang minoritas. Dalam hal ini, Toynbee seperti dikutip Lauer (2003) mengatakan bahwa perkembangan peradaban berkaitan erat dengan karya kreatif kelompok minoritas yang harus memikirkan tanggapan yang tepat atas tantangan sosial dan juga yang mendorong masyarakat memilih alternatif tanggapan yang direncanakannya. Bila elit tidak lagi dapat memenuhi fungsi ini, maka peradaban akan mengalami kemunduran dan selanjutnya kematian. Pendapat Toynbee tersebut memperlihatkan dua hal yang penting kepada kita, yakni bahwa kehadiran elit dapat mempercepat sekaligus memperlambat perubahan. Hal ini dibuktikan dengan studi Martindale yang menunjukkan bahwa elit intelektual telah menjadi sumber penting yang mendorong ke arah perubahan

\subsection{Akses Terhadap Pembangunan: Pendekatan Aktor}

Definisi akses yang digunakan dalam riset ini merujuk pada Peluso (2003:1) yang mengartikan akses sebagai kemampuan untuk memperoleh manfaat dari sesuatu. Definisi ini lebih luas dari pengertian klasik tentang properti, yang didefinisikan sebagai hak untuk memperoleh manfaat dari sesuatu ("the right to benefit from things"). Akses dalam definisi Peluso mengandung makna "sekumpulan kekuasaan" ( "a bundle of powers") berbeda dengan properti yang memandang akses sebagai "sekumpulan hak" ("a bundle of rights"). Sehingga relasi properti utamanya yang berkenaan dengan klaim atas hak, maka untuk memperoleh manfaat dari pembangunan termasuk dalam hal ini, namun tidak terbatas pada, relasi properti. 
Kekuasaan, menurut Peluso, terdiri atas elemen-elemen material, budaya dan ekonomi-politik yang berhimpun sedemikian rupa membentuk "bundel kekuasaan" (bundle of powers) dan "jaring kekuasaan" (web of powers) yang kemudian menjadi penentu akses ke sumber daya. Implikasi dari definisi Peluso ini adalah bahwa kekuasaan yang inheren terkandung di dalam dan dipertukarkan melalui berbagai mekanisme, proses dan relasi sosial akan mempengaruhi kemampuan seseorang atau institusi untuk memperoleh manfaat dari pembangunan. Mengingat elemen-elemen material, budaya, ekonomi dan politik tidak statis, maka kekuasaan dan akses yang terbentuk dalam pembangunan juga berubah-rubah menurut ruang dan waktu. Dengan kata lain, individu dan institusi mempunyai posisi yang berbeda-beda dalam relasinya dengan pembangunan pada ruang dan waktu yang berbeda (Peluso 2003).

\subsection{Pendekatan dengan Teori konflik}

Lahirnya teori konflik terinspirasi dari teoretisi neo-Marxis, yang berintikan pergulatan antar kelas ekonomi. Sosiolog Jerman, Ralf Dahrendorf, menerangkan konflik kelas dalam masyarakat industrial yang begitu rupa dalam konfigurasi tatanan sosial. Teori ini sangat berbeda dari teori Marx karena ia menganalisis konflik tanpa memperhitungkan politik ekonomi yang ada (apakah kapitalisme atau sosialisme). Jika Marx bersandar pada pemilikan alat produksi, maka Dahrendorf bersandar pada control atas alat produksi. Dalam terminologi Dahrendorf, pada masa poskapitalisme, kepemilikan akan alat produksi (baik sosialis atau kapitalis) tidak menjamin adanya kontrol atas alat produksi. Jadi, di luar Marxisme, ia mengembangkan beberapa terminologi dari Max Weber, antara lain bahwa sistem sosial itu dikoordinasi secara imperatif melalui otoritas/kekuasaan. Secara sederhana dapat dikatakan bahwa teori Dahrendorf melakukan kombinasi antara fungsionalisme (tentang struktur dan fungsi masyarakat) dengan teori (konflik) antar kelas sosial.

Teori sosial Dahrendorf berfokus pada kelompok kepentingan konflik yang berkenaan dengan kepemimpinan, ideologi, dan komunikasi di samping tentu saja berusaha melakukan berbagai usaha untuk menstrukturkan konflik itu sendiri, mulai dari proses terjadinya hingga intensitasnya dan kaitannya dengan kekerasan. Jadi bedanya dengan fungsionalisme jelas, bahwa ia tidak memandang masyarakat sebagai sebuah hal yang tetap/statis, namun senantiasa berubah oleh terjadinya konflik dalam masyarakat. Dalam menelaah konflik antara kelas bawah dan kelas atas misalnya, Dahrendorf menunjukkan bahwa 
kepentingan kelas bawah menantang legitimasi struktur otoritas yang ada. Kepentingan antara dua kelas yang berlawanan ditentukan oleh sifat struktur otoritas dan bukan oleh orientasi individu pribadi yang terlibat di dalamnya. Individu tidak harus sadar akan kelasnya untuk kemudian menantang kelas sosial lainnya.

Sementara itu, menurut George Simmel (1858-1918), sosiolog fungsionalis Jerman juga telah mencoba mendekati teori konflik dengan menunjukkan bahwa konflik merupakan salah satu bentuk interaksi sosial yang mendasar; berkaitan dengan sikap bekerja sama dalam masyarakat. Dalam hal ini Simmel mungkin salah seorang sosiolog pertama yang berusaha keras untuk mengkonstruksi sistem formal dalam sosiologi yang diabstraksikan dari sejarah dan detil pengalaman manusia. Analisisnya tentang efek ekonomi uang dalam perilaku manusia merupakan salah satu pekerjaannya yang penting.

Bertitik berat pada konsekuensikonsekuensi terjadinya konflik pada sebuah sistem sosial secara keseluruhan. Teorinya menunjukkan kekeliruan jika memandang konflik sebagai hal yang selalu merusak sistem sosial, karena konflik juga dapat memberikan keuntungan pada masyarakat luas di mana konflik tersebut terjadi. Konflik justru dapat membuka peluang integrasi antar kelompok. Lewis Coser (2003).

\section{PEMBAHASAN}

\subsection{Perubahan Sosial di Propinsi} Banten Prespektif Peran Jawara dalam Politik

Asal-usul kata "Jawara" sesungguhnya tidaklah begitu jelas. Sebagian orang berpendapat bahwa Jawara berarti Juara, yang berarti pemenang, yang ingin dipandang orang yang paling hebat. Memang bahwa salah satu sifat Jawara adalah selalu ingin menang, yang terkadang dilakukan dengan berbagai cara termasuk dengan cara yang tidak baik. Sehingga seorang Jawara itu biasa bersifat sompral (berbicara dengan bahasa yang kasar dan terkesan sombong), sebagian orang lagi berpendapat bahwa kata "Jawara" berasal dari kata "Jaro" yang berarti seorang pemimpin yang biasanya merujuk kepada kepemimpinan di desa, yang kalau sekarang lebih dikenal dengan kepala desa atau lurah. Pada masa dahulu kepala desa atau lurah di Banten itu mayoritas adalah para Jawara. Para Jawara tersebut memimpin kajaroan (desa) namun kemudian terjadi pergeseran makna sehingga Jawara dan Jaro menunjukan makna yang berbeda. Sekarang ini Jawara tidak mesti menjadi pemimpin, apalagi menjadi kepala desa atau lurah. 
Menurut Tihami (2003), bahwa Jawara itu adalah murid kiyai. Kiyai di Banten pada tempo dulu tidak hanya mengajarkan ilmu-ilmu agama Islam tetapi mengajarkan ilmu persilatan atau kanuragan. Hal ini disebabkan pesantren, pada masa yang lalu, berada di daerahdaerah terpencil dan kurang aman, karena kesultanan tidak mampu menjangkau daerah-daerah yang terpencil yang sangat jauh dari pusat kekuasaan. Murid kiyai yang lebih berbakat dalam bidang intelektual, mendalami ilmu-ilmu agama Islam pada akhirnya disebut santri. Sedangkan murid kiyai yang memiliki bakat dalam bidang fisik lebih condong kepada persilatan atau ilmu-ilmu kanuragan, yang kemudian disebut Jawara. Karena itu dalam tradisi kejawaran bahwa seorang Jawara yang melawan perintah kiyai itu akan kawalat. Mungkin atas dasar itu seorang pengurus persilatan dan seni budaya Banten menyatakan bahwa Jawara itu adalah khodim (pembantu) nya kiyai. Bahkan seperti yang diungkapkan salah seorang kiyai di Serang. Juwara iku tentarane kiyai (Jawara itu tentaranya kiyai).

Istilah Jawara dalam percakapan sehari-hari masyarakat Banten sekarang ini dipergunakan untuk istilah denotatif dan juga referensi untuk mengidentifikasi seseorang. Istilah Jawara yang menunjukan referensi untuk identifikasi seseorang adalah gelar bagi orang-orang yang memiliki kekuatan fisik dalam bersilat dan mempunyai ilmu-ilmu kesaktian (kadigjayaan), seperti kekebalan tubuh dari senjata tajam, bisa memukul dari jarak jauh dan sebagainya, sehingga membangkitkan perasaan orang lain penuh dengan pertentangan: hormat dan takut, rasa kagum dan benci. Sedangkan istilah Jawara yang bersifat denotatif berisi tentang sifat yang merendahkan derajat (derogatif) yang biasanya digunakan untuk orang-orang yang berprilaku sombong, kurang taat menjalankan perintah agama Islam atau melakukan sesuatu dengan cara-cara yang tidak baik terhadap orang untuk kepentingan dirinya semata, seperti melakukan ancaman, kekerasan dan kenekadan.

Karena itu kesan orang terhadap istilah Jawara cenderung negatif dan derogatif. Maka ada orang yang mendefenisikan Jawara dengan "jago wadon lan lahur" (tukang main perempuan dan tukang bohong), "jago wadon lan harta" (tukang main perempuan dan tamak harta). Kesan yang kurang baik tentang Jawara tersebut yang kemudian bagi orang-orang yang memiliki ilmu-ilmu kadigjayaan atau persilatan yang sudah "terpelajar" tidak mau menamakan dirinya Jawara tetapi lebih senang disebut pendekar. 
Persepsi masyarakat tentang jawara saat ini yang kurang simpatik dan cenderung negatif sebenarnya bisa diterangkan dengan teori " bandit sosial" di atas. Peranan Jawara pada masa lalu yang menonjolkan keberanian untuk melawan musuh bersama masyarakat yakni: pemerintah kolonial Belanda, mendapat penghargaan dan penghormatan di mata rakyat Banten. Karena itu Jawara dianggap pahlawan oleh rakyat, sebagai pembela dan pelindung atas kepentinganya. Peran-peran itu yang telah ditampilkan secara baik oleh Mas Jakaria serta tokoh-tokoh Jawara masa silam. Namun setelah Indonesia bebas dari kolonialisme, musuh bersama rakyat itu tidak ada. Namun prilaku-prilaku Jawara, seperti sompral, sombong, kurang taat dalam beragama, justru tidak berubah, sehingga menimbulkan antipati masayarakat terhadap Jawara.

Tokoh-tokoh agama, kiyai, terutama dari pemimpin tarekat, selain dipandang sebagai orang yang mengerti tentang pesan-pesan dan ajaran-ajaran agama juga dipandang sebagai sosok yang paling dekat dengan pusat kekuatan supernatural, karena itu dipercayai memiliki kekuatan magis dan mistis, yang lebih dikenal dengan ilmu-ilmu hikmah. Karena kharisma seseorang kiyai akan semakin besar apabila ia selain memiliki kemampuan untuk memahami ajaranajaran agama, terutama kitab-kitab kuning juga dipercayai oleh masayarakat memiliki kekuatan mistis dan magis yang besar pula, sehingga ia dianggap bisa melakukan perbuatan-perbuatan yang tidak bisa dilakukan oleh orang-orang biasa.

Tokoh lain di wilayah Banten yang memiliki status sosial yang dihormati dan disegani karena dianggap memiliki kemampuan untuk memanipulasi kekuatan supra-natural yang merupa magis dan mistis adalah Jawara. Jawara dianggap memiliki ilmu-ilmu kedigjayaan (kesaktian) dan menguasai ilmu persilatan. Selain itu Jawara juga harus memiliki keberanian (wanten, kawani) secara fisik, yang keberaniannya itu didukung oleh kemampuan dirinya dalam menguasai ilmu bela diri (persilatan) dan ilmu-ilmu kesaktian. Karena itu seseorang yang hanya memiliki ilmu-ilmu kadigjayaan dan persilatan tidak akan dinamakan Jawara apabila ia tidak memiliki keberanian. Karena kelebihannya yang dimilikinya itu maka Kiyai dan Jawara dipandang sebagai pemimpin masyarakat dan merupakan "elit sosial" di masyarakat Banten.

Kedua tokoh tersebut memiliki pengaruh yang cukup besar di masyarakat dan juga memiliki para pengikut yang setia. Kepemimpinannya bersifat kharismatik, yakni: kepemimpinan yang bertumpu kepada daya tarik pribadi yang melekat pada diri pribadi seorang kiyai atau Jawara tersebut. Karena posisinya 
yang demikian itu maka seorang kiyai atau Jawara dapat selalu dibedakan dari orang kebanyakan. Juga karena keunggulan kepribadiannya itu, ia dianggap bahkan diyakini memiliki kekuatan supernatural sehingga memiliki kemampuan luar biasa dan mengesankan di hadapan khalayak banyak.

Menurut masyarakat Banten gelar Kiyai diberikan kepada seorang yang "terpelajar" dalam pemahaman keislamannya dan ia membaktikan hidupnya "demi mencari ridha Allah" untuk menyebarluaskan serta memperdalam ajaran-ajaran agama Islam kepada seluruh masyarakat melalui lembaga pendidikan ataupun pesantren, yang menyandang gelar tersebut biasanya memiliki kesaktian dan ahli kebatinan, ahli hikmah, guru dan pemimpin masyarakat yang berwibawa yang memiliki legitimasi berdasarkan kepercayaan masyarakat. Sedangkan jawara dalam pandangan masyarakat Banten merujuk kepada seseorang atau kelompok yang memiliki kekuatan fisik dalam bersilat (kanuragan) dan mempunyai ilmu-ilmu kesaktian (kadigjayaan), seperti kekebalan tubuh dari senjata tajam, bisa memukul dari jarak jauh dan sebagainya, sehingga membangkitkan perasaan hormat dan takut, rasa kagum dan benci. Berkat kelebihannya itu, ia bisa muncul menjadi tokoh yang kharismatik, terutama pada saat-saat kehidupan sosial mengalami krisis.

Kyai dalam masyarakat Banten merupakan tokoh panutan masyarakat yang dihormati berkat perannya dalam mengarahkan dan menata kehidupan bermasyarakat. Sedangkan jawara berkedudukan sebagai pemimpin dari lembaga adat masyarakat diapun tokoh yang dihormati apabila ia menjadi pemimpin atau penguasa. Keduanya merupakan pemimpinan yang memiliki pengaruh pada masyarakat Banten, kebesaran namanya sangat ditentukan oleh nilai-nilai pribadi yang dimiliki, kemampuan dalam penguasaan ilmu pengetahuan (agama dan sekuler), kesaktian dan keturunannya. Peranan kiyai dalam masyarakat Banten adalah sebagai tokoh masyarakat (kokolot), guru ngaji, guru kitab, guru tarekat, guru ilmu "hikmah" (ilmu ghaib) dan sebagai mubaligh.

Peranan seorang kiyai selain sebagai pewaris tradisi keagamaan juga pemberi arahan atau tujuan kehidupan masyarakat yang mesti ditempuh. Karena itu ia lebih bersifat memberikan pencerahan terhadap masyarakat, semua itu menjadi masyarakat Banten yang madani dan memiliki religiusitas yang tinggi, peran-peran seperti itu sangat diperlukan, apalagi bagi masyarakat yang masih mencari jati dirinya. Sedangkan Jawara 
lebih cenderung kepada kekuatan fisik dan "batin". Sehingga dalam masyarakat Banten peran-peran yang sering dimainkan oleh para jawara adalah menjadi Jaro (kepala desa atau lurah), guru ilmu silat dan ilmu "batin" atau magic, satuan-satuan pengamanan.

Peranan tersebut bagi masyarakat sangat membantu apalagi saat Banten dalam kekacauan dan kerusuhan yang cukup lama, namun demikian peranan para jawara dalam sosial, ekonomi dan politik dalam kehidupan masyarakat Banten saat ini sangat diperlukan. Tetapi akhir-akhir ini peranan para Jawara mulai berbeda dibandingkan dengan peranan jawara pada masa-masa lalu dalam sejarah kehidupan masyarakat Banten sesuai perkembangan zaman.

Begitu pula ketika mereka membina hubungannya dengan sesama Kiyai dan jawara disatukan dalam ruang lingkup kebudayaan Banten. Sifat hubungan keduanya tidak hanya bersifat simbiosis, yakni saling ketergantungan tetapi juga kontradiktif. Jawara membutuhkan elmu dari kiyai, sedangkan sebaliknya kiyai, atas jasanya tersebut, menerima uang shalawat (bantuan material) dari jawara. Tetapi juga banyak kiyai yang tidak senang terhadap berbagai prilaku Jawara yang sering menghalalkan segara cara walau dengan cara kekerasaan dalam menyelesaikan masalah.
Struktur yang ada di masyarakat yang berupa sekelompok Jawara Banten yang membentuk dirinya sangat mumpuni di dalam merubah tatanan kehidupan yang ada di Propinsi Banten, sehingga mereka membuat organisasi dengan merubah nama Jawara menjadi Pendekar. Yang tokohnya adalah almarhum H. Tb. Hasan Sochib.

Di jaman reformasi pasca Orde Baru, setelah dilaksanakannya pemilihan Kepala daerah Propinsi Banten (pemilihan gubernur), para calon pemimpin pertama yang memperebutkan kursi gubernur di Propinsi Banten ada beberapa kandidat, termasuk putri sulung jawara setempat, yakni Atut Chosiyah putri H. Tb. Hasan Sochib. Dialah yang kemudian keluar sebagai pemenang. Perspektif ini bersumber pada sekelompok elit yang mempunyai peran penting dalam perubahan sosial. Meski kategori elit sangat beragam, akan tetapi terdapat kecenderungan umum dari kelompok ini yakni jumlahnya yang minoritas. Dalam hal ini, Toynbee seperti dikutip Lauer (2003) mengatakan bahwa perkembangan peradaban berkaitan erat dengan karya kreatif kelompok minoritas yang harus memikirkan tanggapan yang tepat atas tantangan sosial dan juga yang mendorong masyarakat memilih alternatif tanggapan yang direncanakannya.

Kelompok minoritas ini yang di pimpin oleh $\mathrm{H}$. Tb. Hassan Sachib dengan 
para Jawaranya karena telah membuat organisasi, akhirnya di kuasai, dan para Jawara memasuki ranah pemerintahan dari berbagai lini, untuk mengambil keuntungan dari pembangunan yang di jalankan oleh pemerintahan propinsi Banten.

Masuknya pendekar menjadi bagian struktural di Propinsi Banten karena mempunyai kreatifitas untuk menguasai segala kekayaan Banten, dan menjadi mayoritas di dalam, sehingga masyarakat Banten mulai tidak menyukai peranan para Jawara/pendekar yang sudah kehilangan fungsinya terdahulu yang selalu memikirkan kepentingan masyarakat dan meminta nasihat dari kiyai, dan kini sudah berubah.

\subsection{Pendekatan Aktor}

Peranan dari pendekar pimpinan $\mathrm{H}$. Tb. Hassan Sochib di Propinsi Banten yang mayoritas merambah cakarnya hingga ke kabupaten/kota yang ada di propinsi Banten dan menjadi raja jelmaan untuk memperkaya segelintir orang dari pembangunan yang ada di Banten.

Relasi sosial yang sudah terbangun oleh H. Tb. Hassan Sochib sehingga merasuk ke dalam tubuh pemerintahan Banten. Menurut Peluso (2003) bahwa individu dan institusi mempunyai posisi yang berbeda-beda dalam relasinya dengan pembangunan pada ruang dan waktu yang berbeda serta perananan individu mempunyai pengaruh yang sangat kuat. Peranan H. Hassan di wilayah pemerintahan walau secara tidak langsung masuk dalam struktur, kecuali anaknya yang menjadi gubernur, dan beberapa kabupaten/kota yang sudah dikuasai.

Pengaruhnya yang sangat luas tersebut membentuk bundel kekuasaan dalam ekonomi-politik serta jaringan kekuasaan yang kuat, untuk memperkokoh dari cangkramnya. Sehingga membentuk tirani kecil yang ada di wilayah dan masyarakat menyebut $H$. Hasan sebagai Gubernur Jenderal serta tidak simpatik lagi akan peranannya di Banten.

\subsection{Gerakan Masyarakat Banten}

Perubahan sosial yang terjadi di masyarakat Banten terkait dengan pengaruh yang dibangun oleh gerakan sosial atau social movement. Gerakan sosial tersebut dilakukan oleh kelompok atau organisasi masyarakat yang kurang respek terhadap pemerintahan yang di nilai oleh beberapa kalangan pada saat ini kurang memperhatikan masyarakatnya Banten. Gerakan sosial yang dilakukan merupakan kekuatan yang melekat dengan sifat emosional dan konflik yang mempunyai sebab-sebab sehingga terjadinya gerakan. Selain itu, dapat pula dikatakan bahwa gerakan sosial berbentuk representasi perubahan dari bawah dengan 
pengorganisasian masanya serta respon stimulan dari bentuk sosial dan elit politik

Dalam sosiologi, teori konflik berdasar pada asumsi dasar bahwa masyarakat atau organisasi berfungsi, di mana individu dan kelompoknya berjuang untuk memaksimumkan keuntungan yang diperolehnya; secara tak langsung dan tak mungkin dihindari adalah perubahan sosial yang besar seperti revolusi dan perubahan tatanan politik. Teori konflik ini secara umum berusaha memberikan kritiknya pada fungsionalisme yang meyakini bahwa masyarakat dan organisasi memainkan peran masing-masing sedemikian seperti halnya organ-organ dalam tubuh makhluk hidup.

Intinya adalah bahwa ada empat hal yang penting dalam memahami konfilk sosial yang ada di masyarakat Banten saat ini, antara lain: pertama kompetisi untuk mendapatkan sumber daya yang ada di Banten, yang ketika pembagian kue kekuasaan di nilai kurang adil. Yang menjadi dasar interaksi masyarakat Banten, bukanlah KONSENSUS seperi yang ditawarkan fungsionalisme, namun lebih kepada KOMPETISI. Kedua, Ketidaksamaan structural karena di isi dengan unsur KKN di dalam pemerintahan banten. Ketidaksamaan dalam hal Kekuasaan yang selalu di kendalikan oleh seorang gubernur jenderal $(\mathrm{H}$. Tb. Hassan Sichab), di pemerintahan Banten. Ketiga,
Individu dan kelompok yang ingin mendapatkan keuntungan dan berjuang untuk mencapai tujuannya. keempat, Perubahan sosial secara menyeluruh di banten terutama pengembalian kembali akan fungsi Jawara sebagai asset budaya masyarakat Banten.

Harper (1989) juga menjelaskan beberapa tipe-tipe gerakan sosial yang terdiri dari empat dimensi yaitu: (1) gerakan umum yang memiliki tujuan inklusif dan tersebar akan tetapi miskin akan artikulasi yang sentimentil, juga rumusannya terkadang samar dan gerakan spesifik yang cenderung memiliki tujuan, ideologi dan organisasi yang sempit dan fokus; (2) gerakan radikal yang mengusung perubahan fundamental dari sistem, bukan hanya perubahan dalam sistem dan gerakan reformis yang lebih menekankan perubahan dalam sistem yang sudah ada; (3) gerakan instrumental berusaha mendorong perubahan struktur dalam masyarakat dan gerakan ekspresif yang lebih menekankan perubahan pada karakter individual dan perilakunya; serta (4) gerakan sayap kiri yang lebih progresif dan utopian serta gerakan sayap kanan yang lebih konservatif. Selain keempat tipe tersebut, Wilson (1973) dalam Harper (1989) menjelaskan empat tipe kombinasi dari gerakan sosial yaitu gerakan reformatif, alternatif, transformatif, dan redemptif. Dapat juga dikatakan bahwa 
gerakan reformatif dan transformatif merupakan gerakan bersifat progresif atau utopi, sedangkan gerakan alternatif dan redemptif merupakan gerakan bersifat konservatif yang kontras.

\subsection{Perbandingan Teori Dalam Analisis Perubahan Sosial di Banten}

Perbandingan teori di dalam menganalisa peran jawara dalam perubahan sosial di masyarakat Banten serta kelebihan dan kelemahan masing-masing teori dapat dikemukakan dalam bagan di bawah ini:

\begin{tabular}{|c|c|}
\hline Teori Struktural Fungsional & Teori Konflik \\
\hline $\begin{array}{l}\text { 1. Karena di dalam teori struktural fungsional } \\
\text { dalam menganalisa perubahan sosial yang } \\
\text { ada di masyarakat banten prespektif peran } \\
\text { jawara ini bahwa struktur kepemimpinan } \\
\text { yang ada di Banten dapat mendefenisikan } \\
\text { akan kelas-kelas yang ada di Banten. }\end{array}$ & $\begin{array}{l}\text { 1. Dengan menggunakan pisau analisis } \\
\text { teori konflik untuk menghadapi } \\
\text { pergulatan antar kelompok sosial yang di } \\
\text { masyarakat Banten, bahwa gerakan } \\
\text { sosial di banten sebagai representasi } \\
\text { perubahan dari bawah ke atas yang } \\
\text { merupakan gerakan yang muncul secara } \\
\text { orisinil dari massa grass-roots dan } \\
\text { direspon oleh elit. Perubahan juga dapat } \\
\text { distimulasi dan dimanipulasi oleh elit } \\
\text { untuk menciptakan solidaritas dan } \\
\text { komitmen. }\end{array}$ \\
\hline $\begin{array}{l}\text { 2. Dalam teori ini kelemahan yang sangat } \\
\text { kentara guna menganalisanya adalah tidak } \\
\text { bisa memecahkan dalam permasalahan } \\
\text { struktur kelas dan kurangnya akan } \\
\text { mengkritisi Terhadap perubahan atau terlalu } \\
\text { konservatif dalam melihat struktur yang ada } \\
\text { di banten. }\end{array}$ & $\begin{array}{l}\text { 2. pada teori konflik kelemahan dalam } \\
\text { menganalisa peranan jawara banten ini } \\
\text { adalah kurangnya akan tatanan yang } \\
\text { lebihbaik dalam melaksanakan sebuah } \\
\text { pergerakan sosial yang dapat di terima } \\
\text { pada masyarakat banten. Atau dalam } \\
\text { artian terlalu revolusioner. }\end{array}$ \\
\hline
\end{tabular}





\section{KESIMPULAN}

Berdasarkan hal tersebut di atas maka dapat di simpulkan bahwa adanya kedudukan, peran Jawara menciptakan kultur tersendiri yang agak berbeda dengan kultur dominan masyarakat Banten, sehingga Jawara tidak hanya menggambarkan suatu sosok tetapi juga telah menjadi kelompok yang memiliki nilai, norma dan pandangan hidup yang khas.

Jawara adalah seorang atau sekelompok yang memiliki kekuatan fisik dalam bersilat dan mempunyai ilmu-ilmu kesaktian (kadigjayaan), seperti kekebalan tubuh dari senjata tajam, bisa memukul dari jarak jauh dan sebagainya, sehingga bagi orang lain dapat membangkitkan rasa hormat dan takut, serta kagum dan benci. Karena kelebihannya itu, ia dapat menjadi seorang tokoh yang kharismatik, terutama pada saat-saat kehidupan sosial mengalami krisis.

Sementara itu, peranan sosial Jawara di dalam perpolitikan lokal banten karena tidak adanya akan control social yang baik di banten, maka Jawara merambah pada peranannya ke level pemerintahan banten dan menduduki akan segala lini untuk mendapatkan kepentingan dan keuntungannya.

Hal tersebut harus di jegah dengan cara penguatan terhadap masyarakat akan pengetahuan dan kesadaran akan kepentingan KEBANTENAN berupa mengembalikan akan Jawara pada asset budaya, dan nilai-nilai akan kejawaraan memang harus di junjung tinggi bagi masyarakat banten. Sehingga perubahan social yang ada akan terasa baik di kemudian hari.

\section{DAFTAR PUSTAKA}

Castles, Lance et.al., Birokrasi, Kepemimpinan, dan Perubahan Sosial di Indonesia. Surakarta: Penerbit HAPSARA, 1986.

Carney, Michael, The Co-Evolution of Institutional Environments and Organozational Strategie: The Rise of Family Business Groups in The Asean Region. Concordia University, 2005.

Harper, Charles L., Exploring Social Change. New Jersey: Prentice Hall, 1989.

Lauer, Robert H., Perspektif tentang Perubahan Sosial. Jakarta: Rineka Cipta, 2003.

Tihami, Perilaku Politik Jawara Banten dalam Proses Politik di Banten, Jakarta: UI Press, 2003..

Sztompka, Piotr, Sosiologi Perubahan Sosial, Jakarta: Pernada Media, 2005.

Weber, Max, Sosiologi, Yogyakarta: Pustaka Pelajar, 2006.

Wertheim, W.F., Gelombang Pasang Emansipasi; Evolusi dan Revolusi, Yogyakarta: Garba Budaya \& ISAI, 1999. 